\title{
The transition to agricultural cultivation of neo-crops may fail to account for wild genetic diversity patterns: insights from the Cape Floristic Region
}

\author{
Nicholas C Galuszynski ${ }^{\text {Corresp. } 1}$ \\ ${ }^{1}$ Department of Botany, Nelson Mandela University, Gqebehra, South Africa \\ Corresponding Author: Nicholas C Galuszynski \\ Email address: nicholas.galuszynski@gmail.com
}

Aim: The global increase in the cultivation of native wild plants has raised concerns regarding potential risks associated with translocating genetic lineages beyond their natural range. This study aimed to investigate whether agricultural cultivation of neo-crops a) accounts for the levels of genetic diversity present in wild populations, and whether b) cultivated populations are genetically divergent from wild populations and thus pose a potential threat to wild genetic diversity.

Location: The Cape Floristic Region (CFR), located along the southern Cape of South Africa.

Methods: High Resolution Melt analysis (HRM) coupled with Sanger sequencing was used to screen three non-coding chloroplast DNA loci in Cyclopia Vent. (Fabaceae), a CFR endemic neo-crop cultivated for the production of a herbal infusion referred to as Honeybush tea. Wild and cultivated populations for three of three widely cultivated Honeybush species (C. intermedia, C. longifolia, and C. subternata) were screened. Genetic diversity and differentiation were measured and compared between wild and cultivated groups.

Results: Across all asseccions, a total of 17 haplotypes were detected, four of which were shared between wild and cultivated populations, while the remaining 13 were only detected in wild populations. Genetic diversity and differentiation was significantly higher in wild populations than in cultivated populations.

Conclusions: If no guidelines exist to facilitate the introduction of native wild plant taxa to a cultivated setting, wild genetic diversity patterns are likely to be compromised by cultivated populations. In the case presented here, cultivation represents a genetic bottleneck, failing to account for rare haplotypes, and may have disrupted species boundaries by initiating interspecific hybridization. More empirical work is required to evaluate the extent to which neo-crop cultivation poses a risk to wild genetic resources in the CFR and globally. 
1 The transition to agricultural cultivation of neo-crops may fail

2 to account for wild genetic diversity patterns: insights from

\section{Introduction}

5 Commercial trade of wild crop and medicinal plants relies predominantly on material sourced

6 from wild populations. However, consumer demand for 'natural products' and products

7 manufactured from renewable resources has promoted an increase in the domestication and

8 cultivation of wild crop species (Lubbe and Verpoorte 2011), referred to here as neo-crops. If

9 managed effectively, cultivation could facilitate the preservation of these economically

10 important species by safeguarding genetic diversity ex-situ. Alternatively, widespread

11 cultivation may reduce incentives to protect natural populations, with natural populations

12 being replaced by cultivated ones. Additionally, the cultivation of commercial strains adjacent

13 to natural populations may increase the risk of exposing wild plants to non-local genetic

14 lineages that may result in hybridization, and thus, genetic erosion (Hammer and Teklu 2008;

15 Laikre et al. 2010).

16 Gene flow from cultivated to wild populations is particularly common in traditional crop

17 systems (Ellstrand et al. 1999) and can negatively impact wild populations by disrupting local

18 genetic diversity and adaptation (Laikre et al. 2010). Neutral and selective pressures result in

19 the divergence of ecological and genetic traits among geographically separate populations

20 (Hufford and Mazer 2003). When this geographic separation is overcome due to

21 anthropocentric translocation of genetic material, the fate of non-local genes that escape into

22 wild populations is challenging to predict. There have, however, been cases where non-local

23 lineages have invaded native populations, resulting in a loss of local genetic diversity (e.g. Carex

24 caryophyllea Latourr (Cyperaceae), Whitlock et al. 2010; and Phragmites australis (Cav.) Steud, 
25 Chambers et al. 1999). A precautionary approach that limits the distance that genetic material

26 is translocated should, therefore, be adopted during anthropogenic redistribution of genetic

27 material (Byrne and Stone 2011; Galuszynski and Potts 2020a). This is rarely the case, and the

28 evolutionary history of the taxa involved is often not considered. Rather, in many cases, seed is

29 sourced from distant populations or seed lots and have already undergone some form of

30 screening for individuals with commercially favorable traits (Hyten et al. 2006; Schipmann et al.

31 2005; Tembrock et al. 2017; Yuan et al. 2010), that may be detrimental when introduced to

32 natural populations.

33 Cultivated populations are likely to be poor representatives of local genetic diversity. In the 34 case of the stimulant plant qat (Catha edulis [Vahl] Forssk. ex Endl., Celastraceae), genotypes 35 sourced from wild populations in Ethiopia were used to establish cultivated populations in Yemen and Kenya, yet both regions support genetically distinct natural qat populations that could have formed the basis for local cultivation (Tembrock et al. 2017). In contrast, cultivated populations of the Chinese skullcap (Scutellaria baicalensis Georgi, Lamiaceae) contained a combination of haplotypes sourced from multiple, geographically separate, wild populations, lacking the phylogeographic structuring present in wild populations (Yuan et al. 2010). Despite representing different approaches to collecting genetic material for cultivation, if gene flow were to occur from cultivated to wild populations in either of these cases, the genetic integrity of wild populations would be compromised.

The Cape Floristic Region (CFR; Goldblatt 1978), located on the southern coast of South Africa is well known for its species richness, supporting over 9000 species in an area of approximately $90000 \mathrm{~km}^{2}$ (Goldblatt and Manning 2002), and home to various economically important plant species (Reinten et al. 2011; Scott and Hewett 2008; Turpie et al. 2003). The high floristic diversity of this region has resulted from low extinction rates in a topographically and edaphically heterogeneous landscape, which produces steep ecological gradients and isolate populations over relatively short distances (Barraclough 2006; Cowling et al. 2009; Cowling et al. 2017). Genetic divergence (within and among species) in the CFR is therefore possible over relatively short distances, producing plant populations that exhibit spatially structured genetic 
54 is thus, an ideal system for testing the representation of wild genetic variation in cultivated 55 neo-crop plants.

56 The commercial trade in South African plant products relies predominantly on raw material 57 sourced from wild populations (van Wyk and Prinsloo 2018). However, species used for the production of products with high export value are becoming widely cultivated (Reinten et al.

59 2011; Turpie et al. 2003). This transition to cultivation may pose a threat to the genetic integrity

60 of wild populations of the target species, as the underlying levels and distribution of genetic 61 diversity are not considered during the selection and translocation of commercially important 62 CFR plants (van Wyk 2008). The consequences of this have already led to interspecific 63 hybridization among Protea L. species (Proteaceae) (Macqueen and Potts 2018) and possible 64 genetic erosion of wild Rooibos (Aspalathus linearis (Burm.f.) R.Dahlgren, Fabaceae) (Malgas et al. 2010). As a result, concerns regarding potential genetic risk associated with a shift to widespread cultivation of Honeybush tea - a herbal infusion produced from members of the CFR endemic genus Cyclopia Vent (Fabaceae) - have been raised (Potts 2017).

The global increase in demand for Honeybush tea, coupled with local declines in wild populations, prompted interest in cultivation (Joubert et al. 2011). Initial breeding trials included 12 of the 23 Cyclopia species and involved the selection of individuals with commercially favorable traits (e.g. bushy and vigorous growth forms), and cross pollination experiments (Joubert et al. 2011). Seed produced from these trials formed the foundation of early Honeybush cultivation, which was promoted in areas that supported natural Cyclopia populations (Jacobs 2008; Joubert et al. 2011). This history of domestication trials and translocation is not unique to Honeybush, with a similar approach applied to neo-crops elsewhere in Southern Africa (Akinnifesi et al. 2006), Australia (Ahmed and Johnson 2000), and South Korea (Pemberton and Lee 1996), and may be typical of neo-crop development.

This study is the first to describe the levels of genetic diversity among wild and cultivated populations of an endemic crop plant originating from the CFR, focusing specifically on three widely cultivated Cyclopia species. High Resolution Melt analysis (HRM, Wittwer et al. 2003) coupled with sequence confirmation is applied to screen variation across two non-coding 
82 chloroplast DNA (cpDNA) regions (the atpl - atpH intergenic spacer and ndhA intron). This study

83 explores the prediction that cultivated Cyclopia populations will fail to reflect the spatial

84 distribution and diversity of chloroplast lineages present in the wild. Thus, the current state of

85 honeybush cultivation, and likely neo-crop cultivation in general, may represent a genetic risk

86 to the integrity of wild populations occurring in close proximity to cultivated populations.

\section{Methods and materials}

\section{Target taxa and sampling}

89 The species selected for evaluation (C. intermedia E.Mey, C. subternata Vogel., and C. longifolia

90 Vogel.) represent the most widely cultivated Honeybush taxa, cultivated in the Western Cape

91 and Eastern Cape provinces of South Africa (Joubert et al., 2011; McGregor 2017).

92 Consequently, these three species have likely experienced the greatest extent of redistribution

93 outside of their natural range through cultivation (Fig 1; Fig 3 in Joubert et al., 2011) - placing

94 them at high risk of genetic pollution. Additionally, these species represent three distinct

95 distribution and life history patterns (Schutte 1997): a widespread obligate resprouter occurring

96 at altitudes between 500 - 1700 m (C. intermedia), a widespread coastal lowland obligate

97 seeder (C. subternata) and a critically endangered Eastern Cape endemic, riparian specialist

98 with a mixed post fire response of facultative seeding and sprouting ( $C$. longifolia). Since life

99 history traits and range size impact a species' demographic history (Ellegren and Galtier 2016),

100 these three taxa are likely to exhibit different genetic diversity patterns that need to be

101 accounted for during translocation and cultivation.

102 Two of these species (C. Intermedia and C. Subternata) were subject of recent phylogeographic

103 studies (Galuszynski and Potts 2020a; 2020c) and these previously published data sets were

104 bolstered with additional samples to ensure that 24 individuals were available from each

105 populations for analysis. Samples were collected from four geographically separated wild

106 populations across the natural range of each species. The intention was to a) maximise the

107 genetic variation detected among populations, and b) provide a representative reference of 
108 haplotypes to describe the origins of material under cultivation. Cultivated material was

109 sampled from Honeybush farms identified remotely from internet searches rather than relying

110 on existing farmer networks, and were located in different mountain ranges (details of the

111 locations are provided in Fig 1 and Table 1). This approach was employed to avoid potentially

112 redundant sampling of cultivated material originating from seed exchange between farmers

113 located in close proximity to one another, however, the true origin of the commercial seed

114 remains uncertain (see discussion). The cultivators included in the study are situated near to

115 three of the four major Honeybush nurseries reported by Joubert et al. (2011) (Fig 1). Three

116 cultivated populations of each species were sampled. From all populations (wild and

117 cultivated), a total of 24 plants were sampled with a minimum of $5 \mathrm{~m}$ distance between sampled

118 individuals. The final data set consisted of 504 samples collected across 21 (12 wild, 9

119 cultivated) populations of three commercially important Cyclopia species, population locations

120 are mapped in Fig. 1. Fresh leaf material was collected from a healthy growing tip of each

121 individual and placed into silica desiccating medium for a minimum of two weeks prior to DNA

122 extraction. All sampling was approved by the relevant landowners involved and permitting

123 agencies, Cape Nature (Permit number: CN35-28-4367), the Eastern Cape Department of

124 Economic Development, Environmental Affairs and Tourism (Permit numbers: CRO 84/ 16CR,

125 CRO 85/ 16CR), and the Eastern Cape Parks and Tourism Agency (Permit number: RA_0185)

\section{DNA extraction and haplotype detection}

127 The DNA extraction and haplotype detection protocol followed the approach previously

128 described in Galuszynski and Potts (2020c) and a brief overview of the approach is provided

129 here. Whole genomic DNA was extracted using a modified CTAB DNA extraction approach,

130 adapted from Doyle \& Doyle (1987). Extracted DNA was quantified using a NanoDrop 2000c

131 Spectrophotometer (Thermo Fisher Scientific, Wilmington, DE19810r Scientific, USA) and

132 diluted to $5 \mathrm{ng} / \mu \mathrm{L}$ for PCR amplification and subsequent HRM analysis.

133 High Resolution Melt analysis involves the gradual heating of PCR products amplified in the

134 presence of a DNA saturating dye. As the double stranded DNA is heated it dissociates at a rate 
135 based on the binding strength of the nucleotide sequence under analysis. As such, different

136 nucleotide sequences should produce a distinct melt curve when plotting sample differences in

137 measured fluorescence against change in temperature.

138 Three DNA fragments from two non-coding cpDNA regions (atpl-atpH intergenic spacer and 139 ndhA intron) were amplified using Cyclopia specific primers and subsequently screened for 140 nucleotide variation via HRM curve analysis. Samples were run in duplicates and HRM clustering 141 was conducted on a single population basis following the recommendations of Dang et al. 142 (2012). This was achieved by grouping populations using the 'well group' option in the CFX 143 Manager Software (Bio-Rad Laboratories, Hercules, California, U.S.A.) and running the HRM 144 clustering on these predefined population well groups. All reactions (PCR amplification and 145 subsequent HRM) took place in a 96 well plate CFX Connect (Bio-Rad Laboratories, Hercules, 146 California, U.S.A.). Haplotype melt curve grouping was achieved using the automated clustering 147 algorithm of the High Precision Melt software (Bio-Rad Laboratories, Hercules, California, 148 U.S.A.) $(\Delta \mathrm{Tm}=0.05$, curve shape sensitivity $=70 \%$, temperature correction $=20)$. HRM cluster 149 to haplotype confirmation was achieved by unidirectional sequencing, as described in 150 Galuszynski and Potts (2020c). The chloroplast regions targeted by HRM were sequenced for a 151 subset of individuals per HRM cluster from populations not previously studied by Galuszynski 152 and Potts (2020a; 2020c). A total of 39 individuals for the atpl-atpH intergenic spacer and 36 153 individuals for the ndhA intron were PCR amplified using the reverse primers and following PCR 154 protocols of (Shaw et al. 2007) and sequenced. The PCR and HRM conditions and details of the 155 primers used in this study, are provided in S1.

156 Sequences were assembled using CondonCode Aligner [v2.0.1] (CodonCode Corp, http://www. 157 codoncode.com). Each base-call was assigned a quality score using the PHRED base-calling 158 program (Ewing et al. 1998). Sequences were then automatically aligned using ClustalW 159 (Thompson et al. 1994) and visually inspected. All indels that were difficult to score (due to 160 homopolymer repeats that are prone to alignment errors) were removed. The cpDNA regions 161 under investigation are maternally inherited in tandem and not subject to recombination 162 (Reboud \& Zeyl 1994), and were therefore combined for subsequent analysis. A custom R script 
163 (provided with a minimum working example online:

164 https://doi.org/10.6084/m9.figshare.12624620.v1) was then used to assign each sample its

165 respective haplotype identity based on HRM clustering.

\section{Haplotype diversity analysis}

167 All analyses were performed in $R$ [v3.5.1] (R Core Team 2018). The genealogical relationships

168 among haplotypes were established using a Statistical Parsimony (SP) network (Fig. 2)

169 constructed in TCS [v1.2.1] (Clement et al. 2000). As TCS treats each base pair in an indel as an

170 evolutionary event, all indels were reduced to a single base pair prior to analysis with default

171 options selected for network construction. Haplotype diversity and differentiation was

172 compared between wild and cultivated individuals grouped by species and origin. Differences in

173 gene diversity (GD) between wild and cultivated populations were tested via Mantel tests

174 (Mantel 1967); using Hs.test function implemented in the adegenet [v2.1.1] library, (Jombart \&

175 Ahmed 2011). Genetic differentiation between wild and cultivated populations were tested via

176 an Analysis of Molecular Variance (AMOVA) (Excoffier et al. 1992) using the poppr.amova

177 function with 999 permutations implemented in the poppr [v2.8.3] library (Kamvar et al. 2014).

178 Three additional population differentiation measures were calculated: two fixation indices,

179 pairwise Gst (Nei 1973) and G"'"st (Hedrick 2005), and a measure of genetic divergence, Jost's D

180 (Jost 2008), using the pairwise_Gst_Nei, pairwise_Gst_Hendrick, and pairwise_D functions

181 respectively, all from the mmod [v1.3.3] library (Winter 2012). Population clustering was

182 inferred from a Neighbor Joining tree constructed using Prevostis pairwise population genetic

183 distance (Prevosti et al. 1975), calculated using the prevosti.dist function in the poppr library).

184 This distance measure treats alignment gaps as evolutionary events and all gaps were reduced

185 to a single base pair prior to analysis. Support for population clustering was assessed via a

186 bootstrap analysis with 9999 replicates, implemented using the aboot function implemented in 187 poppr.

188 Results 


\section{Haplotype detection}

190 Of the 504 samples screened for haplotype variation, seven (six wild and one cultivated) failed to

191 PCR amplify despite repeated efforts and the final dataset consisted of 497 samples. High

192 Resolution Melt analysis with haplotype confirmation by sequencing revealed 17 cpDNA

193 haplotypes with 100\% specificity for all three loci (i.e. no cases of different haplotypes being

194 grouped into the same HRM cluster were detected). The final concatenated dataset consisted

195 of $794 \mathrm{bp}$ (457 bp from the atpl-atpH intergenic spacer and $339 \mathrm{bp}$ from the $n d h A$ intron) with

196 an overall GC content of $28.1 \%$. The alignment contained 22 polymorphic sites including nine

197 transitions, ten transversions, and three indels (two of $7 \mathrm{bp}$ and one of $71 \mathrm{bp}$ ). Haplotype

198 frequency within populations and nucleotide variation among haplotypes are summarized in

199 Tables 1 and 2, respectively.

\section{Genetic diversity analysis}

201 The SP network (Fig 2) revealed relatively low divergence among haplotypes, with all

202 haplotypes diverging from a central variant. Of the 17 haplotypes detected, only four were

203 present in cultivated populations. These four haplotypes (in addition to a fifth haplotype,

204 detected only in wild C. subternata and C. intermedia populations from Garcia's Pass, GAR Fig 1)

205 were shared among species. Two of these haplotypes were detected in C. intermedia

206 populations (wild and cultivated) and cultivated C. subternata populations, but were not

207 present in any wild C. subternata populations screened.

208 Clustering of Cyclopia populations, based on pairwise population genetic distance resulted in

209 weak grouping of species. Cultivated populations, however, exhibited little differentiation and

210 generally clustered together based on species (Fig 3). Similarly, wild C. longifolia populations

211 exhibited little genetic differentiation and all wild and cultivated populations of this species

212 formed a single group (Fig 3). Wild C. intermedia and C. subternata populations tended to

213 exhibit higher levels of genetic divergence. All cultivated C. subternata populations were

214 clustered with two wild populations originating from the Tsitsikamma mountains (Kareedouw

215 Pass KAR, and Bloukrans Bridge BKB). The remaining wild $C$. subternata populations were more 
216 divergent and did not cluster with other $C$. subternata populations. The $C$. intermedia and $C$.

217 subternata populations sampled from Garcia's pass (GAR) exhibited no genetic differentiation

218 (both fixed for haplotype F). In general, wild C. intermedia populations tended to be genetically

219 distinct, supporting unique haplotypes and formed no clear clusters in the Neighbor Joining

220 population tree (Fig 3). Cultivated C. intermedia populations did not exhibit this variability.

221 Rather, all cultivated $C$. intermedia populations form a single cluster with the wild $C$. intermedia

222 population sampled from the Langkloof (LK).

223 In the cases of $C$. subternata and $C$. intermedia, genetic structuring was detected in wild 224 populations, with $60.1 \%$ and $83.3 \%$ of genetic variation detected among populations for the 225 two species, respectively (associated Fst values significant, $p<0.005$, Fst $=0.093$ and 0.023 , 226 respectively). In contrast, no structuring was detected in cultivated populations of these 227 species, with $4.3 \%$ and $1.7 \%$ of variation structured within cultivated populations for $C$. 228 intermedia and C. subternata, respectively ( $p<0.005$, Fst $=0.0001$ for both species). No genetic 229 structuring was found for wild or cultivated C. longifolia populations, as all populations shared 230 the same common haplotype and only two rare haplotypes ( $\mathrm{N}$ and $\mathrm{M}$, Fig 2) were detected in 231 wild populations. Gene diversity and genetic differentiation followed a similar pattern, with 232 wild C. intermedia and C. subternata populations having higher mean diversity than cultivated 233 populations $(\mathrm{p}<0.01)$, but no differences in gene diversity was detected between wild and 234 cultivated C. longifolia populations. Mean genetic differentiation (Gst, G"st and Josts D) was 235 higher in all wild populations than in cultivated populations. All population differentiation and 236 diversity measures are summarized in Table 3.

\section{Discussion}

238 This study set out to explore haplotype diversity patterns in wild and cultivated populations of

239 Honeybush, an endemic neo-crop from the Cape Floristic Region (CFR) of South Africa.

240 Cultivated populations appear to have originated from a small number of founding populations 241 and/or individuals and represent a genetic bottleneck. Thus, cultivated populations tend to lack 
242 the genetic diversity and phylogeographic structuring present in wild populations and may

243 represent a genetic threat to wild populations if gene-flow occurs.

\section{Origin of cultivated genetic diversity}

245 Despite initial Cyclopia breeding material originating from multiple wild populations (Joubert et

246 al. 2011, Fig 1), screening for individuals with commercially desirable traits has likely removed

247 much of the haplotype richness from commercial breeding stock. The transition to Honeybush

248 cultivation therefore represents a genetic bottleneck - under representing rare haplotypes

249 and homogenizing the cultivated genepool.

250 Based on the NJ clustering of populations (Fig 3), cultivated C. intermedia have likely originated

251 from populations located in the Langkloof (LK); C. subternata populations from the Tsitsikamma

252 and/or Outeniqua mountains (these wild populations share the same common haplotype found

253 in cultivated populations); while C. longifolia originates from its only known wild source, the

254 Van Stadens River system. These findings are consistent with those from recent microsatellite

255 analysis of $C$. subternata (Niemandt et al. 2018). They compared wild populations from the

256 Tsitsikamma and Outeniqua mountains to the Agricultural Resource Council's (ARC) commercial

257 genebank (an important source of commercially traded Honeybush seed), revealing no genetic

258 differentiation between the two wild populations sampled and the genebank accessions. The

259 lack of haplotype diversity detected in cultivated populations is therefore unlikely to be a

260 byproduct of failing to detect variation in the slow evolving chloroplast genome (Schaal et al.

261 1998), as greater divergence was detected among populations originating from the

262 Tsitsikamma or Outeniqua mountains using cpDNA screening via HRM than in the microsatellite 263 based study.

264 The history of the movement of cultivated seed remains speculative and conversations with 265 cultivators during sampling revealed that seed is largely sourced from existing farmer networks 266 in their respective areas (with the initial origin of seed unknown). However, C. subternata 267 cultivated in Harkerville $(\mathrm{H})$ was confirmed to have been established from commercial seed and 268 did not differ in dominant haplotypes from other cultivated populations. Furthermore, 
269 Harkerville shared a rare haplotype with cultivated material from Uniondale (U) - where

270 putative hybrids were detected (N.C. Galuszynski personal observations, 2018, leaf material

271 from these individuals was collected and is stored at the Nelson Mandela University in Port

272 Elizabeth, South Africa). This rare haplotype was only detected in wild C. intermedia

273 populations located in the Swartberg Mountains (SWB) and may be evidence of possible

274 chloroplast capture (Hansen et al. 2003) resulting from interspecific crosses taking place during

275 the initial breeding trials (Joubert et al. 2011) or under field cultivation. The reasoning behind

276 this argument is two fold. First, the chloroplast regions screened exhibit phylogeographic

277 structuring in both species (Galuszynski and Potts 2020a, 2020c) and it is therefore unlikely that

278 a wild C. subternata population will support this rare haplotype outside of the Swartberg

279 mountains (where $C$. subternata does not naturally occur). Secondly, $C$. intermedia and $C$.

280 subternata have been found to successfully produce hybrid offspring with other members of

281 the genus under experimental conditions, and $C$. intermedia material from the Swartberg was

282 included in the initial Honeybush cultivation trials (Joubert et al. 2011, Fig 1). However,

283 interspecific hybridization should be investigated through additional molecular work targeting

284 the nuclear genome, which is subject to recombination and provides more insight into

285 introgression history.

286 Potential impacts of cultivated genetic material on wild populations

287 Higher levels of genetic diversity were detected in wild Cyclopia populations than cultivated 288 populations, with multiple cases of near complete haplotype turnover among wild populations 289 (Table 1) - cultivated populations exhibited nearly no differentiation (Table 3). This level of 290 haplotype turnover and genetic structuring of cpDNA in the wild was expected and has been 291 described in detail for C. intermedia (Galuszynski and Potts 2020a) and C. subternata 292 (Galuszynski and Potts 2020c). This suggests that there may be a tendency for cultivated 293 populations to fail to account for natural phylogeographic patterns in regions where genetic 294 structuring of plant populations occurs, including regions that may play a significant role in the 295 discovery of neo-crops (eg. Mesoamerica, Ornelas et al. 2013; South America, Turchetto-Zolet 
296 et al. 2013; Australia, Byrne 2008; the Mediterranean basin, Feliner 2014; and the Cape of

297 South Africa, Galuszynski and Potts 2020b, Tolley et al., 2014).

298 Genetic diversity differed between species (Table 3), suggesting different demographic histories

299 among these closely related taxa (Ellegren and Galtier 2016). Notably, rare and locally endemic

300 taxa are predicted to have low levels of genetic variation due to their restricted distributions

301 and small population sizes (Ellstrand and Elam 1993; Gitzendanner and Soltis 2000; Segarra-

302 Moragues et al. 2012), evident in wild C. Longifolia populations. The redistribution of genetic

303 lineages via neo-crop cultivation needs to account for differences in demographic histories.

304 Local endemics, for instance, may be at greater genetic risk from cultivated variants due to

305 naturally low levels of genetic variation being more susceptible to genetic pollution by foreign

306 lineages (Levin et al. 1996; Wolf et al. 2001). Commercial production of narrow endemics may

307 therefore require periodic supplementing of cultivated stands with locally sourced seed

308 material in order to promote the preservation of rare haplotypes.

309 Genetic pollution can only occur if genetic material is able to escape into the wild. Seed

310 dispersal is limited to a few meters in Cyclopia, and one would expect the chances of seed

311 escape to be low. However, unmonitored spillover of cultivated seed into adjacent natural

312 habitat does occur (N. C. Galuszynski, pers. obs. 2017) in addition to rare cases of cultivated

313 plants intentionally established in natural vegetation (N. C. Galuszynski pers. obs. 2017; G.

314 McGregor pers. com. 2016; S. Nortje pers. com. 2019). The chloroplast genome is maternally

315 inherited with no recombination in the majority of angiosperms (Mogensen, 1996) and is,

316 therefore, subject to directional selective sweeps. Thus, the introduction of vigorous maternal

317 lineages from commercial seed lots could disrupt local haplotypes diversity in wild crop plants.

318 While the impacts of foreign haplotypes establishing in wild Honeybush populations is

319 unknown, the introduction of foreign Spartina alterniflora (Poaceae) haplotypes from the

320 United States to native Chinese populations resulted in a hybrid swarm that disrupted local

321 cpDNA genome frequency and ecological processes due to vigorous growth displacing native

322 plant species (Qiao et al., 2019). 
323 Mass flowering of cultivated populations forms a powerful attractant to pollinators, increasing 324 local pollinator density (Holzschuh et al. 2011; Westphal et al. 2003). This facilitates the spread

325 of genetic material from cultivated populations into the wild via pollen flow, particularly in 326 outcrossing species (Ellstrand et al., 1999), such as members of Cyclopia (Keon et al., 2020). By

327 altering local allele frequencies through the introduction of large genetically depauperate 328 commercial plantations, a landscape wide genetic bottleneck may result, promoting erosion of wild genetic diversity. The current state of neo-crop cultivation, relying on low genetic diversity breeding stock that is redistributed outside of its natural range (and possibly containing interspecific hybrid taxa as observed in the Honeybush populations in Uniondale, but requiring further research), represents a genetic threat that should be acknowledged and mitigated.

333 Until the genetic risks are better understood, formal guidelines should be developed to 334 facilitate sustainable cultivation of neo-crops. In the case of Honeybush, an ecology-centric approach, as the one outlined by Potts (2017), may be desired due to the conservation value of many Cyclopia species; including the commercially important taxa: C. longifolia (critically endangered), C. genistoides (near threatened), C. maculata (near threatened), C. plicata (endangered), and C. sessiliflora (near threatened). However, it is unlikely that all neo-crops will exhibit the levels of phylogeographic structuring, genetic diversity and, conservation requirements of Cyclopia, and more work is required to define the extent to which wild genetic resources are at risk during neo-crop cultivation practices, particularly in species rich landscapes such as the Cape of South Africa.

\section{References}

344 Ahmed AK, Johnson KA. 2000. Horticultural development of Australian native edible plants.

345 Australian Journal of Botany 48: 417-426. https://doi:10.1071/BT99042

346 Akinnifesi FK, Kwesiga F, Mhango J, Chilanga T, Mkonda A, Kadu CAC, Kadzere I, Mithofer D, 347 Saka JDK, Sileshi G, Ramadhani T, Dhliwayo P. 2006. Towards the development of Miombo fruit 348 trees as commercial tree crops in Southern Africa. Forests, Trees And Livelihoods 16: 103-121 349 https://doi:10.1080/14728028.2006.9752548 
350 Barraclough, T.G., 2006. What can phylogenetics tell us about speciation in the Cape flora?.

351 Diversity \& Distributions, 12: 21-26. https://doi.org/10.1111/j.1366-9516.2006.00208.x

352 Britton, M.N., Hedderson, T.A., Verboom, G.A., 2014. Topography as a driver of cryptic 353 speciation in the high-elevation cape sedge Tetraria triangularis (Boeck.) C. B. Clarke

354 (Cyperaceae: Schoeneae). Molecular Phylogenetics and Evolution 77: 96-109.

355 https://doi.org/10.1016/j.ympev.2014.03.024

356 Byrne, M., 2008 Evidence for multiple refugia at different time scales during Pleistocene 357 climatic oscillations in southern Australia inferred from phylogeography. Quaternary Science 358 Reviews 27: 2576-85. https://doi.org/10.1016/j.quascirev.2008.08.032

359 Byrne, M., Stone, L., 2011. The need for 'duty of care' when introducing new crops for 360 sustainable agriculture. Current Opinion in Environmental Sustainability 3: 50-54.

361 https://doi.org/10.1016/j.cosust.2010.11.004

362 Chambers, R.M., Meyerson, L.A., Saltonstall, K., 1999. Expansion of Phragmites australis into 363 tidal wetlands of North America. Aquatic Botany 64: 261-273. https://doi.org/10.1016/s0304364 3770(99)00055-8

365 Clement, M., Posada, D., Crandall, K.A., 2000. TCS: a computer program to estimate gene 366 genealogies. Molecular Ecology 9: 1657-1659. https://doi.org/10.1046/j.1365-

$367294 x .2000 .01020 . x$

368 Cowling, R.M., Bradshaw, P.L., Colville, J.F., Forest, F., 2AD. Levyns law: explaining the evolution 369 of a remarkable longitudinal gradient in Cape plant diversity. Transactions of the Royal Society 370 of South Africa 72:184-201. https://doi.org/10.1080/0035919x.2016.1274277

371 Cowling, R.M., Procheş, Ş., Partridge, T.C., 2009. Explaining the uniqueness of the Cape flora: 372 Incorporating geomorphic evolution as a factor for explaining its diversification. Molecular 373 Phylogenetics and Evolution 51: 64-74. https://doi.org/10.1016/j.ympev.2008.05.034

374 Dang, X.D., Kelleher, C.T., Howard-Williams, E., Meade, C.V., 2012. Rapid identification of 375 chloroplast haplotypes using High Resolution Melting analysis. Molecular Ecology Resources 12: 376 894-908. https://doi.org/10.1111/j.1755-0998.2012.03164.x

377 Doyle, J.J., Doyle, J.L., 1987. A rapid DNA isolation procedure for small quantities of fresh leaf 378 tissue. Phytochemical Bulletin 19: 11-15.

379 Ellegren, H., Galtier, N., 2016. Determinants of genetic diversity. Nature Reviews Genetics 17: 380 422-433. https://doi.org/10.1038/nrg.2016.58 
381 Ellstrand, N.C., Elam, D.R., 1993. Population genetic consequences of small population size: 382 implications for plant conservation. Annual Review of Ecology and Systematics 24: 217-242.

383

384

385

386

387

388

389

390

391

392

393

394

395

396

397

398

399

400

401

402

403

404

405

406

407

408

409

410

411 https://doi.org/10.1146/annurev.es.24.110193.001245

Ellstrand, N.C., Prentice, H.C., Hancock, J.F., 1999. Gene flow and introgression from domesticated plants into their wild relatives. Annual Review of Ecology and Systematics 30: 539-563. https://doi.org/10.1146/annurev.ecolsys.30.1.539

Ewing, B., Hillier, L., Wendl, M.C., Green, P., 1998. Base-calling of automated sequencer traces using Phred. I. accuracy assessment. Genome Research 8: 175-185.

https://doi.org/10.1101/gr.8.3.175

Excoffier, L., Smouse, P.E., Quattro, J.M., 1992. Analysis of molecular variance inferred from metric distances among DNA haplotypes: application to human mitochondrial DNA restriction data. Genetics 131: 479-491.

Feliner G.N., 2014 Patterns and processes in plant phylogeography in the Mediterranean Basin. A review. Perspectives in Plant Ecology, Evolution and Systematics 16: 265-78.

https://doi.org/10.1016/j.ppees.2014.07.002

Galuszynski, N.C., Potts, A.J., 2020a. Applied phylogeography of Cyclopia intermedia (Fabaceae) highlights the need for 'duty of care' when cultivating honeybush. PeerJ $8 \mathrm{e} 9818$. https://doi.org/10.7717/peerj.9818

Galuszynski N.C., Potts A.J., 2020b. Do Centres of Endemism provide a spatial context for predicting and preserving plant phylogeographic patterns in the Cape Floristic Region, South Africa? PeerJ 8:e10045 http//doi: 10.7717/peerj.10045

Galuszynski, N.C., Potts, A.J., 2020c. Application of High Resolution Melt analysis (HRM) for screening haplotype variation in a non-model plant genus: Cyclopia (Honeybush). PeerJ 8e9187. https://doi.org/10.7717/peerj.9187

Gitzendanner, M.A., Soltis, P.S., 2000. Patterns of genetic variation in rare and widespread plant congeners. American Journal of Botany 87: 783-792. https://doi.org/10.2307/2656886

Goldblatt, P., 1978. An analysis of the flora of Southern Africa: Its characteristics, relationships, and orgins. Annals of the Missouri Botanical Garden: 365-369. https://doi.org/10.2307/2398858

Goldblatt, P., Manning, J.C., 2002. Plant diversity of the Cape Region of southern Africa. Annals of the Missouri Botanical Garden: 289-281. https://doi.org/10.2307/3298566 
412 Hammer, K., Teklu, Y., 2008. Plant genetic resources: selected issues from genetic erosion to 413 genetic engineering. Journal of Agriculture and Rural Development in the Tropics and 414 Subtropics 109: 15-50

415 Hansen, L.B., Siegismund, H.R., Jørgensen, R.B., 2003. Progressive introgression between

416 Brassica napus (oilseed rape) and B. rapa. Heredity 91: 276-283.

417 https://doi.org/10.1038/sj.hdy.6800335

418 Hedrick, P.W., 2005. A standardized genetic differentiation measure. Evolution 59: 1633-1638.

419 https://doi.org/10.1111/j.0014-3820.2005.tb01814.x

420 Holzschuh, A., Dormann, C.F., Tscharntke, T., Steffan-Dewenter, I., 2011. Expansion of mass-

421 flowering crops leads to transient pollinator dilution and reduced wild plant pollination.

422 Proceedings of the Royal Society B: Biological Sciences 278: 3444-3451.

423 https://doi.org/10.1098/rspb.2011.0268

424 Hufford, K.M., Mazer, S.J., 2003. Plant ecotypes: genetic differentiation in the age of ecological 425 restoration. Trends in Ecology \& Evolution 18: 147-155. https://doi.org/10.1016/s0169426 5347(03)00002-8

427 Hyten, D.L., Song, Q., Zhu, Y., Choi, I.Y., Nelson, R.L., Costa, J.M., Specht, J.E., Shoemaker, R.C., 428 Cregan, P.B., 2006. Impacts of genetic bottlenecks on soybean genome diversity. Proceedings of 429 the National Academy of Sciences 103: 16666-16671.

430 https://doi.org/10.1073/pnas.0604379103

431 Jacobs R. 2008. Honeybush: where can it be cultivated successfully?. Agri-Probe.

432 Jombart, T., Ahmed, I., 2011. adegenet 1.3-1: new tools for the analysis of genome-wide SNP 433 data. Bioinformatics 27: 3070-3071. https://doi.org/10.1093/bioinformatics/btr521

434 Jost, L., 2008. GST and its relatives do not measure differentiation. Molecular Ecology 17: 4015435 4026. https://doi.org/10.1111/j.1365-294x.2008.03887.x

436 Joubert, E., Joubert, M.E., Bester, C., de Beer, D., De Lange, J.H., 2011. Honeybush (Cyclopia 437 spp.): from local cottage industry to global markets - The catalytic and supporting role of 438 research. South African Journal of Botany 77: 887-907.

439 https://doi.org/10.1016/j.sajb.2011.05.014

440 Kamvar, Z.N., Tabima, J.F., Grünwald, N.J., 2014. Poppr: an R package for genetic analysis of 441 populations with clonal, partially clonal, and/or sexual reproduction. PeerJ 2, e281.

442 https://doi.org/10.7717/peerj.281 
443 Koen, J., Slabbert, M.M., Booyse, M., Bester, C., 2020. Honeybush (Cyclopia spp.) anther-stigma 444 distance and intraspecies cross compatibilities. South African Journal of Plant and Soil: 1-6.

445 Laikre, L., Schwartz, M.K., Waples, R.S., Ryman, N., 2010. Compromising genetic diversity in the 446 wild: unmonitored large-scale release of plants and animals. Trends in Ecology \& Evolution 25: 447 520-529. https://doi.org/10.1016/j.tree.2010.06.013

448 Levin, D.A., Francisco-Ortega, J., Jansen, R.K., 1996. Hybridization and the extinction of rare 449 plant species. Conservation Biology 10: 10-16. https://doi.org/10.1046/j.1523-

$450 \quad$ 1739.1996.10010010.x

451 Lubbe, A., Verpoorte, R., 2011. Cultivation of medicinal and aromatic plants for specialty 452 industrial materials. Industrial Crops and Products 34: 785-801.

453 https://doi.org/10.1016/j.indcrop.2011.01.019

454 Macqueen, T.P., Potts, A.J., 2018. Re-opening the case of Frankenflora: evidence of 455 hybridisation between local and introduced Protea species at Van Stadens Wildflower Reserve. 456 South African Journal of Botany 118: 315-320. https://doi.org/10.1016/j.sajb.2018.03.018

457 Malgas, R.R., Potts, A.J., Oettlé, N.M., Koelle, B., Todd, S.W., Verboom, G.A., Hoffman, M.T., 458 2010. Distribution, quantitative morphological variation and preliminary molecular analysis of 459 different growth forms of wild rooibos (Aspalathus linearis) in the northern Cederberg and on 460 the Bokkeveld Plateau. South African Journal of Botany 76: 72-81.

461 https://doi.org/10.1016/j.sajb.2009.07.004

462 Mantel, N., 1967. Ranking procedures for arbitrarily restricted observation. Biometrics: 65-78. 463 https://doi.org/10.2307/2528282

464 McGregor, G.K., 2017. Industry review: an overview of the Honeybush industry. Department of 465 Environmental Affairs and Development Planning, Cape Town.

466

Mogensen, H.L. 1996. The hows and whys of cytoplasmic inheritance in seed plants. American

467 Journal of Botany 83: 383-404. https://doi.org/10.1002/j.1537-2197.1996.tb12718.x

468 Nei, M., 1973. Analysis of gene diversity in subdivided populations. Proceedings of the National 469 Academy of Sciences 70: 3321-3323. https://doi.org/10.1073/pnas.70.12.3321

470 Niemandt, M., Roodt-Wilding, R., Tobutt, K.R., Bester, C., 2018. Microsatellite marker 471 applications in Cyclopia (Fabaceae) species. South African Journal of Botany 116: 52-60.

472 https://doi.org/10.1016/j.sajb.2018.02.408

473 Ornelas, J.F., Sosa, V., Soltis, D.E., Daza, J.M., González, C., Soltis, P.S., Gutiérrez-Rodríguez, C., 474 de los Monteros, A.E., Castoe, T.A., Bell, C. and Ruiz-Sanchez, E., 2013. Comparative 
475 phylogeographic analyses illustrate the complex evolutionary history of threatened cloud

476 forests of northern Mesoamerica. PloS one, 8(2), p.e56283.

477 Pasquet, R.S., Peltier, A., Hufford, M.B., Oudin, E., Saulnier, J., Paul, L., Knudsen, J.T., Herren, 478 H.R., Gepts, P., 2008. Long-distance pollen flow assessment through evaluation of pollinator 479 foraging range suggests transgene escape distances. Proceedings of the National Academy of 480 Sciences 105: 13456-13461. https://doi.org/10.1073/pnas.0806040105

481 Pemberton, R. W., Lee, N. S., 1996. Wild food plants in South Korea; market presence, new 482 crops, and exports to the United States. Economic Botany 50: 57-70.

483 https://doi.org/10.1007/BF02862113

484

485

486

487

488

489

490

491

492

493

494

495

496

497

498

499

500

501

502

503

504

505

506

507

Potts, A.J., 2017. Genetic risk and the transition to cultivation in Cape endemic crops - The example of honeybush (Cyclopia)?. South African Journal of Botany 110: 52-56. https://doi.org/10.1016/j.sajb.2016.09.004

Potts, A.J., Hedderson, T.A., Vlok, J.H.J., Cowling, R.M., 2013. Pleistocene range dynamics in the eastern Greater Cape Floristic Region: A case study of the Little Karoo endemic Berkheya cuneata (Asteraceae). South African Journal of Botany 88:401-413.

https://doi.org/10.1016/j.sajb.2013.08.009

Prevosti, A., Ocaña, J., Alonso, G., 1975. Distances between populations of Drosophila subobscura, based on chromosome arrangement frequencies. Theoretical and Applied Genetics 45: 231-241. https://doi.org/10.1007/bf00831894

Qiao, H., Liu, W., Zhang, Y., Zhang, Y. Y., \& Li, Q. Q. (2019). Genetic admixture accelerates invasion via provisioning rapid adaptive evolution. Molecular ecology, 28(17), 4012-4027. https://doi: 10.1111/mec.15192

Reboud, X., Zeyl, C., 1994. Organelle inheritance in plants. Heredity 72: 132-140. https://doi.org/10.1038/hdy.1994.19

Reinten, E.Y., Coetzee, J.H., van Wyk, B.E., 2011. The potential of South African indigenous plants for the international cut flower trade. South African Journal of Botany 77: 934-946. https://doi.org/10.1016/j.sajb.2011.09.005

Schaal, B.A., Hayworth, D.A., Olsen, K.M., Rauscher, J.T., Smith, W.A., 1998. Phylogeographic studies in plants: problems and prospects. Molecular Ecology 7: 465-474.

https://doi.org/10.1046/j.1365-294x.1998.00318.x

Schipmann, U., Leaman, D.J., Cunningham, A.B., Walter, S., 2005. Impact of cultivation and collection on the conservation of medicinal plants: Global trends and issues. Acta Horticulturae 31-44. https://doi.org/10.17660/actahortic.2005.676.3 
508 Schutte, A.L., 1997. Systematics of the genus Cyclopia Vent. (Fabaceae, Podalyrieae). Edinburgh

509 Journal of Botany 54: 125-170. https://doi.org/10.1017/s0960428600004005

510 Scott, G., Hewett, M.L., 2008. Pioneers in ethnopharmacology: The Dutch East India Company

511 (VOC) at the Cape from 1650 to 1800. Journal of Ethnopharmacology 115: 339-360.

512 https://doi.org/10.1016/j.jep.2007.10.020

513 Tembrock, L.R., Simmons, M.P., Richards, C.M., Reeves, P.A., Reilley, A., Curto, M.A., Meimberg,

514 H., Ngugi, G., Demissew, S., Al Khulaidi, A.W., Al-Thobhani, M., Simpson, S., Varisco, D.M., 2017.

515 Phylogeography of the wild and cultivated stimulant plant qat (Catha edulis, Celastraceae) in

516 areas of historical cultivation. American Journal of Botany 104: 538-549.

517 https://doi.org/10.3732/ajb.1600437

518 Thompson, J.D., Higgins, D.G., Gibson, T.J., 1994. CLUSTAL W: improving the sensitivity of

519 progressive multiple sequence alignment through sequence weighting, position-specific gap

520 penalties and weight matrix choice. Nucleic Acids Research 22: 4673-4680.

521 https://doi.org/10.1093/nar/22.22.4673

522 Tolley, K.A., Bowie, R.C.K., Measey, J.G., Price, B.W., Forest, F., 2014. The shifting landscape of

523 genes since the Pliocene: terrestrial phylogeography in the Greater Cape Floristic Region. In:

524 Allsopp N, Colville JF, Verboom GA, eds. Fynbos: Ecology, Evolution, and Conservation of a

525 Megadiverse Region. Oxford: Oxford University Press. 142-163

526 Turpie, J.K., Heydenrych, B.J., Lamberth, S.J., 2003. Economic value of terrestrial and marine

527 biodiversity in the Cape Floristic Region: implications for defining effective and socially optimal

528 conservation strategies. Biological Conservation 112: 233-251. https://doi.org/10.1016/s0006-

529 3207(02)00398-1

530 Westphal, C., Steffan-Dewenter, I., Tscharntke, T., 2003. Mass flowering crops enhance

531 pollinator densities at a landscape scale. Ecology Letters 6: 961-965.

532 https://doi.org/10.1046/j.1461-0248.2003.00523.x

533 Whitlock, R., Grime, J.P., Burke, T., 2010. Genetic variation in plant morphology contributes to

534 the species-level structure of grassland communities. Ecology 91: 1344-1354.

535 https://doi.org/10.1890/08-2098.1

536 Winter, D.J., 2012. mmod: an R library for the calculation of population differentiation statistics.

537 Molecular Ecology Resources 12: 1158-1160. https://doi.org/10.1111/j.1755-

538 0998.2012.03174.x 
539 Wittwer, C.T., Reed, G.H., Gundry, C.N., Vandersteen, J.G., Pryor, R.J., 2003. High-resolution

540 genotyping by amplicon melting analysis using LCGreen.. Clinical chemistry 49: 853-60.

541 https://doi.org/10.1373/49.6.853

542 Wolf, D.E., Takebayashi, N., Rieseberg, L.H., 2001. Predicting the risk of extinction through

543 hybridization. Conservation Biology 15: 1039-1053. https://doi.org/10.1046/j.1523-

544 1739.2001.0150041039.x

545 Yuan, Q.J., Zhang, Z.Y., Hu, J., Guo, L.P., Shao, A.J., Huang, L.Q., 2010. Impacts of recent

546 cultivation on genetic diversity pattern of a medicinal plant, Scutellaria (Lamiaceae). BMC

547 Genetics 11: 1-13. https://doi.org/10.1186/1471-2156-11-29

548 R Core Team, 2018. R: a language and environment for statistical computing. R foundation for 549 statistical computing, Vienna, Austria.

550 Segarra-Moragues, J.G., Torres-Díaz, C., Ojeda, F., 2012. Are woody seeder plants more prone 551 than resprouter to population genetic differentiation in Mediterranean-type ecosystems?.

552 Evolutionary Ecology 27: 117-131. https://doi.org/10.1007/s10682-012-9586-y

553 Turchetto-Zolet, A.C., Pinheiro, F., Salgueiro, F., Palma-Silva, C., 2013. Phylogeographical

554 patterns shed light on evolutionary process in South America. Molecular ecology 22: 1193-

555 1213. https://doi.org/10.1111/mec.12164

556 van Wyk, A.S., Prinsloo, G., 2018. Medicinal plant harvesting, sustainability and cultivation in 557 South Africa. Biological Conservation 227: 335-342.

558 https://doi.org/10.1016/j.biocon.2018.09.018

559 van Wyk, B.E., 2008. A broad review of commercially important southern African medicinal 560 plants. Journal of Ethnopharmacology 119: 342-355. https://doi.org/10.1016/j.jep.2008.05.029 


\section{Table $\mathbf{1}$ (on next page)}

Summary of wild and cultivated Honeybush (Cyclopia) populations.

Population localities, including population name and abbreviation (used in Fig. 1 and 3), mountain range each population was sampled from, geographic coordinates, number of accessions screened per population $(\mathrm{N})$, number of haplotypes detected per population $(\mathrm{H})$ with haplotypes unique to the population given in parenthesis, and summary of haplotypes found in each population. 


\begin{tabular}{|c|c|c|c|c|c|c|c|c|c|c|c|c|c|c|c|c|c|c|c|c|c|c|c|c|}
\hline \multirow[t]{2}{*}{ Origin } & \multirow[t]{2}{*}{ Species } & \multicolumn{2}{|c|}{ Location } & \multicolumn{2}{|c|}{ GPS co-ordinates } & \multirow[t]{2}{*}{$\mathrm{N}$} & \multirow[t]{2}{*}{$\mathrm{H}$} & \multicolumn{17}{|c|}{ Haplotype } \\
\hline & & Population & Mountain & $x$ & $Y$ & & & A & B & C & $\mathrm{D}$ & $\mathrm{E}$ & $\mathrm{F}$ & G & $\mathrm{H}$ & 1 & $\mathrm{~J}$ & K & $\mathrm{L}$ & M & $\mathrm{N}$ & $\mathrm{O}$ & $\mathrm{P}$ & Q \\
\hline \multirow[t]{9}{*}{ Cultivated } & C. intermedia & George (G) & Outeniqua & -33.93 & 22.32 & 24 & $2(1)$ & - & 23 & - & 1 & - & - & - & - & - & - & - & - & - & - & - & - & - \\
\hline & & $\begin{array}{l}\text { Uniondale } \\
\text { (U) }\end{array}$ & Kammanassie & -33.66 & 23.14 & 24 & 1 & - & 24 & - & - & - & - & - & - & - & - & - & - & - & - & - & - & - \\
\hline & & $\begin{array}{l}\text { Harlem } \\
\text { (HAR) }\end{array}$ & Tsitsikamma & -33.74 & 23.34 & 24 & 2 & 2 & 22 & - & - & - & - & - & - & - & - & - & - & - & - & - & - & - \\
\hline & C. longifolia & George (G) & Outeniqua & -33.99 & 22.36 & 24 & 1 & 24 & - & - & - & - & - & - & - & - & - & - & - & - & - & - & - & - \\
\hline & & $\begin{array}{l}\text { Uniondale } \\
(U)\end{array}$ & Kammanassie & -33.66 & 23.14 & 23 & 1 & 23 & - & - & - & - & - & - & - & - & - & - & - & - & - & - & - & - \\
\hline & & $\begin{array}{c}\text { Plettenberg } \\
\text { Bay (P) }\end{array}$ & Tsitsikamma & -33.93 & 23.48 & 24 & 1 & 24 & - & - & - & - & - & - & - & - & - & - & - & - & - & - & - & - \\
\hline & C. subternata & $\begin{array}{l}\text { Uniondale } \\
\text { (U) }\end{array}$ & Kammanassie & -33.66 & 23.14 & 24 & 3 & - & 2 & 21 & - & - & - & - & - & 1 & - & - & - & - & - & - & - & - \\
\hline & & $\begin{array}{l}\text { Harkerville } \\
(\mathrm{H})\end{array}$ & Outeniqua & -34.04 & 23.23 & 24 & 3 & 1 & - & 22 & - & - & - & - & - & 1 & - & - & - & - & - & - & - & - \\
\hline & & $\begin{array}{c}\text { Plettenberg } \\
\text { Bay (P) }\end{array}$ & Tsitsikamma & -33.93 & 23.48 & 24 & 1 & - & - & 24 & - & - & - & - & - & - & - & - & - & - & - & - & - & - \\
\hline \multirow[t]{12}{*}{ Wild } & C. intermedia & $\begin{array}{c}\text { Garcia's } \\
\text { Pass (GAR) }\end{array}$ & Langeberg & -33.96 & 21.22 & 23 & 1 & - & - & - & - & $\begin{array}{l}2 \\
3\end{array}$ & - & - & - & - & - & - & - & - & - & - & - & - \\
\hline & & $\begin{array}{c}\text { Swartberg } \\
\text { Mountains } \\
\text { (SWB) }\end{array}$ & Swartberg & -33.33 & 22.04 & 23 & $\begin{array}{c}6 \\
(2)\end{array}$ & 1 & 3 & - & - & - & $\begin{array}{l}1 \\
4\end{array}$ & 3 & 1 & 1 & - & - & - & - & - & - & - & - \\
\hline & & $\begin{array}{l}\text { Langekloof } \\
\text { (LK) }\end{array}$ & Kouga & -33.78 & 23.79 & 24 & $\begin{array}{c}2 \\
(1)\end{array}$ & - & $\begin{array}{l}2 \\
3\end{array}$ & - & - & - & - & - & - & - & 1 & - & - & - & - & - & - & - \\
\hline & & $\begin{array}{l}\text { Ladyslpper } \\
\text { (LS) }\end{array}$ & Cockscomb & -33.9 & 25.25 & 24 & $\begin{array}{c}3 \\
(2)\end{array}$ & - & - & - & - & - & 2 & - & - & - & - & $\begin{array}{l}2 \\
1\end{array}$ & 1 & - & - & - & - & - \\
\hline & C. longifolia & $\begin{array}{c}\text { Longmore } \\
\text { Forest } \\
\text { (LMF) }\end{array}$ & Van Stadens & -33.84 & 25.09 & 23 & 1 & $\begin{array}{l}2 \\
3\end{array}$ & - & - & - & - & - & - & - & - & - & - & - & - & - & - & - & - \\
\hline & & $\begin{array}{l}\text { Sand River } \\
\text { (SR) }\end{array}$ & Van Stadens & -33.73 & 25.09 & 24 & $\begin{array}{c}2 \\
(1)\end{array}$ & $\begin{array}{l}1 \\
9\end{array}$ & - & - & - & - & - & - & - & - & - & - & - & 5 & - & - & - & - \\
\hline & & $\begin{array}{l}\text { Longemore } \\
\text { River (LMR) }\end{array}$ & Van Stadens & -33.81 & 25.15 & 23 & $\begin{array}{c}2 \\
(1)\end{array}$ & $\begin{array}{l}1 \\
9\end{array}$ & - & - & - & - & - & - & - & - & - & - & - & - & 4 & - & - & - \\
\hline & & $\begin{array}{c}\text { Van } \\
\text { Stadens } \\
\text { River (VS) }\end{array}$ & Van Stadens & -33.9 & 25.21 & 24 & 1 & $\begin{array}{l}2 \\
4\end{array}$ & - & - & - & - & - & - & - & - & - & - & - & - & - & - & - & - \\
\hline & C. subternata & $\begin{array}{l}\text { Garcia's } \\
\text { Pass (GAR) }\end{array}$ & Langeberg & -33.96 & 21.22 & 24 & 1 & - & - & - & - & $\begin{array}{l}2 \\
4\end{array}$ & - & - & - & - & - & - & - & - & - & - & - & - \\
\hline & & $\begin{array}{l}\text { Outeniqua } \\
\text { Pass (OP) }\end{array}$ & Outeniqua & -33.88 & 22.4 & 24 & $\begin{array}{c}3 \\
(1)\end{array}$ & 1 & - & $\begin{array}{l}1 \\
8\end{array}$ & - & - & - & - & - & - & - & - & - & - & - & 5 & - & - \\
\hline & & $\begin{array}{c}\text { Bloukranz } \\
\text { Bridge } \\
\text { (BKB) }\end{array}$ & Tsitsikamma & -33.97 & 23.65 & 22 & $\begin{array}{c}2 \\
(1)\end{array}$ & - & - & $\begin{array}{l}1 \\
7\end{array}$ & - & - & - & - & - & - & - & - & - & - & - & - & 5 & - \\
\hline & & $\begin{array}{l}\text { Kareedou } \\
\text { Pass (KAR) }\end{array}$ & Tsitsikamma & -33.97 & 24.22 & 23 & 2 & - & - & $\begin{array}{l}1 \\
9\end{array}$ & - & - & - & - & - & - & - & - & - & - & - & - & - & 4 \\
\hline
\end{tabular}




\section{Table 2 (on next page)}

Summary of chloroplast DNA nucleotide differences for the three loci screened by HRM.

Haplotype frequency in each population is reported in Table 1. 


\begin{tabular}{|c|c|c|c|c|c|c|c|c|c|c|c|c|c|c|c|c|c|c|}
\hline \multirow[b]{2}{*}{ Position } & \multicolumn{3}{|c|}{$\begin{array}{l}\text { MLT S1 - MLT S2 } \\
\text { atpl-atpH } \\
\text { intergenic spacer }\end{array}$} & \multicolumn{9}{|c|}{$\begin{array}{l}\text { MLT S3 - MLT S4 } \\
\text { atpl-atpH } \\
\text { intergenic spacer }\end{array}$} & \multicolumn{6}{|c|}{$\begin{array}{c}\text { MLT U1 - MLT U2 } \\
\text { ndhA } \\
\text { intron }\end{array}$} \\
\hline & $4-10$ & $\begin{array}{l}47- \\
110\end{array}$ & $\begin{array}{l}144- \\
150\end{array}$ & 213 & 230 & $\begin{array}{c}294- \\
301\end{array}$ & 308 & 314 & 380 & 388 & 421 & 443 & 503 & 597 & 682 & 717 & 731 & 799 \\
\hline Consensus & 1 & $2 a$ & 3 & G & C & 4 & G & $\mathrm{T}$ & $\mathrm{T}$ & G & $\mathrm{T}$ & C & G & $\mathrm{T}$ & G & C & $\mathrm{G}$ & C \\
\hline
\end{tabular}

Haplotype

\begin{tabular}{|c|c|c|c|c|c|}
\hline A & 1 & . & . & . & . \\
\hline B & 1 & . & . & . & . \\
\hline$C$ & 1 & . & . & . & . \\
\hline $\mathrm{D}$ & 1 & . & . & . & . \\
\hline $\mathrm{E}$ & 1 & $2 b$ & . & . & . \\
\hline $\mathrm{F}$ & 1 & . & . & . & . \\
\hline $\mathrm{G}$ & 1 & . & . & . & . \\
\hline $\mathrm{H}$ & 1 & . & . & . & $\mathrm{t}$ \\
\hline 1 & - & . & . & . & . \\
\hline $\mathrm{J}$ & 1 &. & - & . & . \\
\hline $\mathrm{K}$ & 1 & - & . & . & . \\
\hline $\mathrm{L}$ & 1 & $2 c$ & . & . & . \\
\hline$M$ & 1 & . & . & . & . \\
\hline $\mathrm{N}$ & 1 & . & . & . & . \\
\hline 0 & 1 & . & . & a & . \\
\hline$P$ & 1 & $2 d$ & . & . & . \\
\hline$Q$ & 1 & $2 e$ & . & . & . \\
\hline
\end{tabular}

4

4

4

.. $\mathrm{g}$

4

4

4

4

4

4

4

4

4

.

$4 \quad a$

4

$4 \quad . \quad . \quad$ a

1 - tatctaa; 3 - aaaattt; 4 - tatcccc

$2 a$ - tacagatgaaaggaagggcttcgttttttgaatcctatctaaatttacagtaacagggcaaa;

$2 \mathrm{~b}$ - tacagatgaaaggaagggcttcgttttttgaaaactatctaaatttacagtaacagggcaaa;

$2 \mathrm{c}$ - tacagatgaaaggaaggggttcgttttttgaatcctatctaaatttacagtaacagggcaaa;

$2 \mathrm{~d}$ - taaagatgaaaggaagggcttcgttttttgaatcctatctaaatttacagtaacagggcaaa;

$2 e-$ tatagatgaaaggaagggcttcgttttttgaatcctatctaaatttacagtaacagggcaaa

2

3 


\section{Table 3 (on next page)}

Genetic diversity, fixation and differentiation measures for wild (W) and cultivated (C) Honeybush (Cyclopia) populations.

Significance values are indicated for comparisons of mean genetic diversity, fixation and differentiation between wild and cultivated populations for each species and all species pooled (Total). 
1

\begin{tabular}{|c|c|c|c|c|c|c|c|c|}
\hline Species & Source & $\mathrm{N}$ & $\mathrm{Hr}$ & GD & Gst (SD) & $\mathrm{G}^{\prime \prime} s t$ & Jost's D & Genetic variation (\%) \\
\hline \multirow[t]{2}{*}{ C.intermedia } & $w$ & 94 & 6 & $0.202^{* *}$ & $0.725(0.178)^{* * *}$ & $0.864(0.111)^{* * *}$ & $0.223(0.100)^{* * *}$ & $83.3^{* * *}$ \\
\hline & C & 72 & 2 & 0.004 & $0.022(0.019)$ & $0.043(0.037)$ & $0.0003(0.0003)$ & $4.3^{* * *}$ \\
\hline \multirow[t]{2}{*}{ C.subternata } & w & 93 & 6 & $0.069 * *$ & $0.332(0.344)^{*}$ & $0.493(0.375)^{*}$ & $0.049(0.045)^{*}$ & $60.1^{* * *}$ \\
\hline & C & 72 & 3 & 0.013 & $0.026(0.030)$ & $0.050(0.057)$ & $0.0005(0.0006)$ & $1.7^{* * *}$ \\
\hline \multirow[t]{2}{*}{ C.longifolia } & w & 94 & 2 & 0.008 & $0.050(0.055)$ & $0.093(0.102)$ & $0.001(0.002)$ & 16.3 \\
\hline & C & 71 & 1 & 0 & $0(0)$ & $0(0)$ & $0(0)$ & 0 \\
\hline \multirow[t]{2}{*}{ Total } & w & 281 & 11 & $0.169 * *$ & $0.645(0.292)^{* * *}$ & $0.756(0.298)^{* * *}$ & $0.154(0.097)^{* * *}$ & $85.4^{* * *}$ \\
\hline & c & 215 & 3 & 0.074 & $0.262(0.213)$ & $0.394(0.245)$ & $0.0334(0.028)$ & $28.6^{* *}$ \\
\hline
\end{tabular}

${ }^{*} p<0.05,{ }^{* *} p<0.01,{ }^{* * *} p<0.005$ (Mantel test, Student t-test, Wilcoxon rank sum test). Genetic variation represents variation between populations determined from AMOVA.

2

3 


\section{Figure 1}

Distribution of Cyclopia populations screened for haplotype diversity.

Cyclopia populations indicated by circles, with the colors for wild and cultivated populations for each species indicated. Red stars indicate the locations of Honeybush nurseries, white pentagons indicate the locations of populations initially used for cultivar development for each species respectively. The natural distribution of the three target species is indicated using the same colors used to indicate wild populations and shaded. A) Distribution of $C$. intermedia, in set indicates the study domain in relation to Africa and South Africa; B) distribution of $C$. subternata; and $C$ ) distribution of $C$. longifolia, the initial source of $C$. longifolia breeding material is the same location as the Longmore populations (LMF, LMR) and cultivated material was sourced from G, $P$, and $U$ (in A and B and indicated by a light blue outline). Population naming follows the descriptions in Table 1. Cultivated populations: $G$ = George, $\mathrm{U}=$ Uniondale, $\mathrm{H}=$ Harkerville, $\mathrm{HAR}=$ Harlem, $\mathrm{P}=$ Plettenberg Bay. Wild populations: GAR $=$ Garcia's Pass, SWB $=$ Swartberg Mountains, $L K=$ Langkloof, LS $=$ Lady Slipper, OP $=$ Outeniqua Pass, BKB $=$ Bloukrans Bridge, $\mathrm{KAR}=$ Kareedouw Pass, $\mathrm{LMF}=$ Longmore Forest, $\mathrm{LMR}=$ Longmore River, $\mathrm{SR}=$ Sand River, $\mathrm{VS}=$ Van Stadens River. 
$\triangle$ Putative origin of cuiltivated material Commercial Honeybush nursary
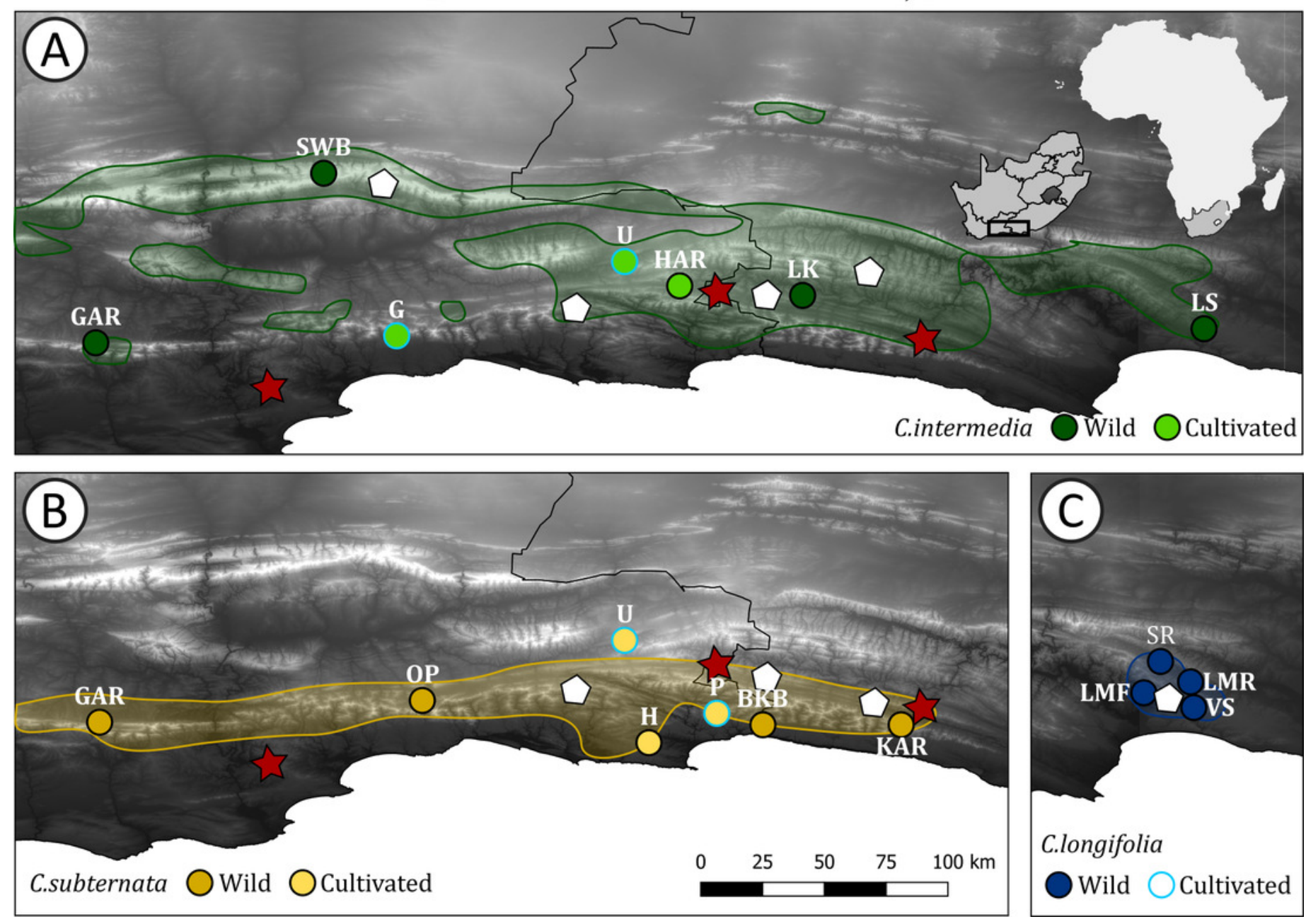


\section{Figure 2}

The relationships among haplotypes from the merging chloroplast DNA regions screened via HRM, as inferred from the statistical parsimony algorithm.

Black circles indicate "missing" haplotypes, whist haplotypes connected by a single line differ by a single nucleotide mutation. Areas of circles and numerical labels correspond to the haplotype frequency. Circle colour indicates the species and source of each haplotype (as denoted by the figure key, with the size of each colour segment corresponding to haplotype frequency. Note that haplotypes A and B occur at low frequencies in some species: A occurs once in cultivated and wild $C$. subternata populations, and once in wild and twice in cultivated C. intermedia populations, B occurs twice in cultivated C. subternata populations. Haplotypes marked with * indicate possible cases of chloroplast capture, as these haplotypes were detected only in cultivated $C$. Subternata populations and wild and cultivated $C$. intermedia populations, but not in any wild $C$. subternata populations. Haplotypes frequencies for each population are given in Table 1 and nucleotide differences among haplotypes are summarized in Table 2. 
C. intermedia (Wild)

C. intermedia (Cultivated)

C. longifolia (Wild)

C. longifolia (Cultivated)

C. subternata (Wild)

C. subternata (Cultivated)

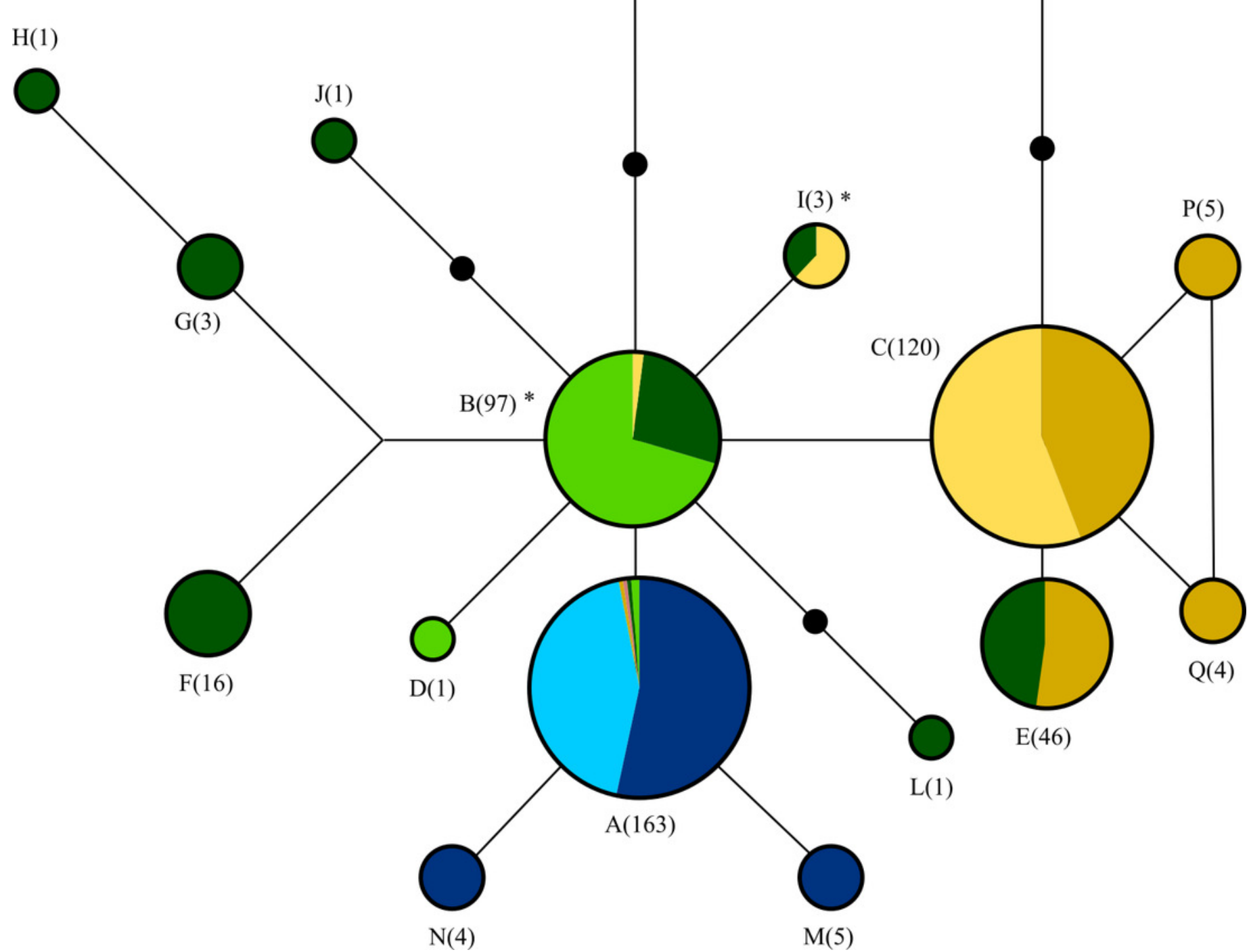




\section{Figure 3}

Unrooted Neighbour Joining clustering diagram of Cyclopia populations based on pairwise population genetic distance.

Branches with over $50 \%$ bootstrap support are labeled. A scale bar of pairwise population genetic distance is provided above the diagram. Branch tips are labeled by species followed by an abbreviated population name following the descriptions Table 1. Open circles indicate wild populations while closed circles indicate cultivated populations. Wild and cultivated populations that group together are indicated by bold type face. 

0.15
0.1
0.05
0

111

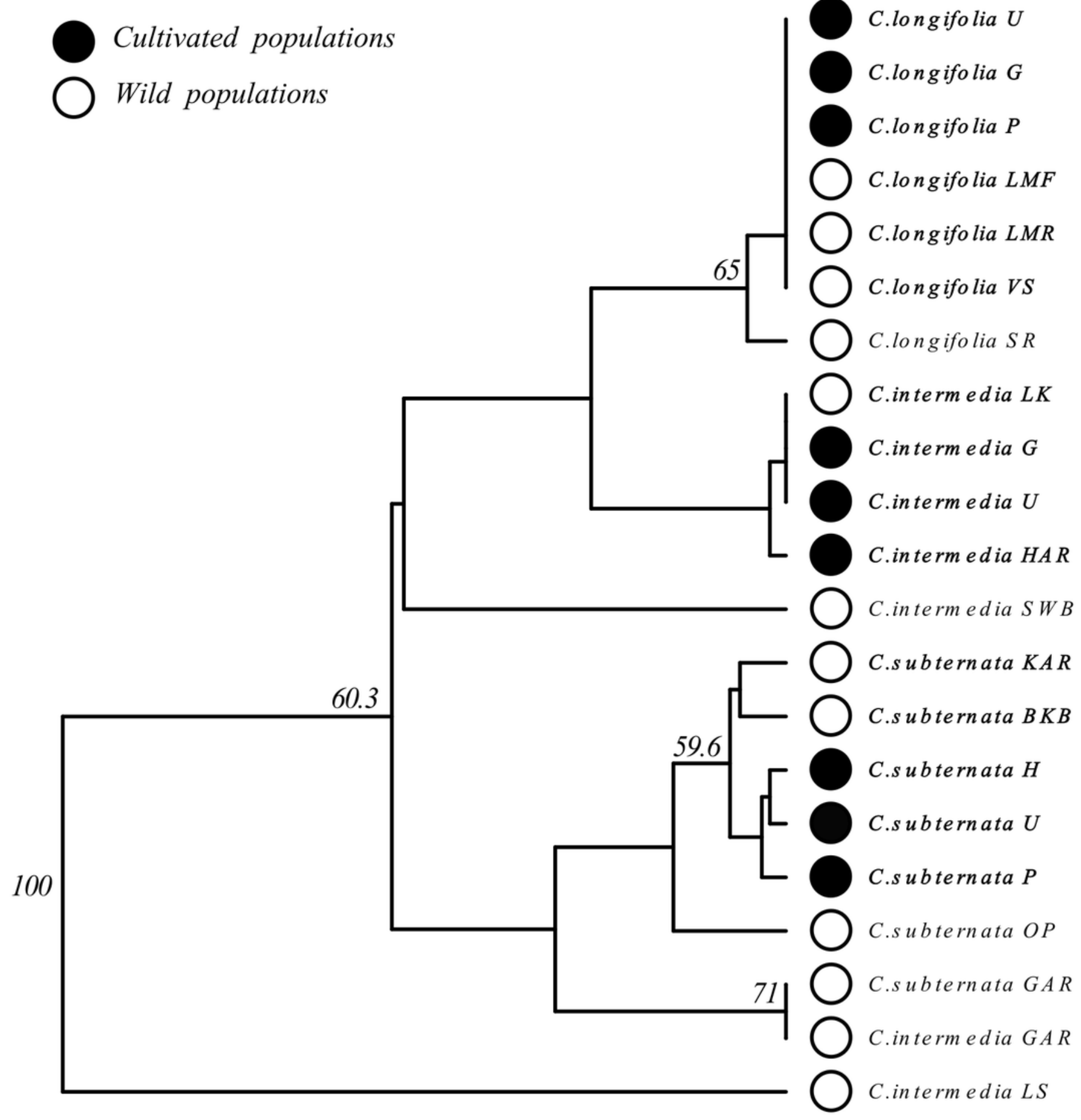

